\title{
The Effect of Environmental Factors on Children from The Viewpoint of Parents
}

\author{
Banu Bekci ${ }^{1} \odot$ \\ ${ }^{1}$ Assoc. Prof. Dr., Faculty of Engineering and Architecture, University of Recep Tayyip Erdogan, Rize, Turkey, Email: \\ banu.bekci@erdogan.edu.tr
}

\begin{abstract} Purpose

The main purpose of this case study is to investigate the effect of increasing negative risk factors on children in outdoor playgrounds. There is a close relationship between children's playgrounds and children's health and safety in the open green areas that are gradually decreasing in the urban landscape. Children are faced with increasing parental concerns (abduction, harassment, self-harm, and inability to socialize), attention deficit in children, obesity and depression diseases. For this reason, the quality and livability of the environment we live in appear as factors that affect the decisions of parents on their children.

Design/Methodology/Approach

In this study, environmental factors and the quality of the environment were examined and the study questioning the concerns of parents about the use of children's playgrounds was discussed in three parts. The first part of the study consists of (i) the examination of children's playgrounds by the parents, the second part consists of (ii) the socio-demographic characteristics of the parents and the third part consists of (iii) the evaluation of the park criteria.

Findings

The findings obtained show that that parents with young children $(2-4$ years $)\left(r=-, 191^{*} ; r=, 214^{* *}\right)$ prefer shopping malls suitable for all weather conditions $\left(\mathrm{r}=, 261^{* *}\right)$ if there is not a playground in the garden of the house lived, but in some cases, the shopping mall is not preferred due to the risk of disease transmission and it brings a serious financial burden to families $\left(\mathrm{r}=-, 163^{*}\right)$, and if the parents are given a chance to prefer, they prefer a natural playground made of natural materials $\left(r=-, 220^{*}\right)$. However, fathers did not prefer to wait at a very close distance for a well-groomed $\left(\mathrm{r}=, 176^{*}\right)$ control $\left(\mathrm{r}=, 228^{*}\right)$ where their children can spend time with their friends $\left(\mathrm{r}=, 247^{* *}\right)$ on weekends alone ( $\mathrm{r}$ $=, 166^{*}$ ), but it was determined that they were worried about their children being excluded and harmed by their friends ( $r=, 249^{* *}$ ).

Research Limitations/Implications

Children are faced with increasing parental concerns (abduction, harassment, self-harm, and inability to socialize), attention deficit in children, obesity and depression diseases.

\section{Originality/Value}

These data show that "play" has positive effects on children's health, and provides benefit in exploring children's creativity, sharpening their thinking skills and environmental awareness. Based on the results of the article, suggestions were developed on how designers, planners and park managers can implement the results in order to eliminate parents' fears and increase their motivation to take their children to children's playgrounds.
\end{abstract}




\section{INTRODUCTION}

Children's playgrounds and public spaces create opportunities for individuals to interact and socialize (Smoyer-Tomic et. al., 2004; Belknap \& Hazler, 2014). These opportunities offer individuals to be selfsufficient, strengthen their individual lifestyles with social ties, and even allow them to restructure neighborly relations (Blackford, 2004). In child rights conventions adopted by the United Nations in 1989, play and relaxation concepts are defined as a right for children (UNICEF TURKEY, 2019). Playing in the open area positively affects not only a child's physical development but also his/her personal development. Many studies on children's playgrounds emphasize that spaces with nature or natural elements help children learn by contributing to their psychological, cognitive, sensory, physical, social and motor development, and also emphasize that they develop their imagination and creativity (Acar, 2013). Farley (2008) and his colleagues stated that play equipment has a strong effect on children's playgrounds, and activities have a moderate effect. For this reason, in order to maximize physical activity in children, activity and variety of game equipment in children's playgrounds are emphasized. Especially in cases where there is no or limited access to open green areas or playgrounds in city centers, the games of children of different age groups should be designed separately so that they do not interfere with each other (Acar, 2016). With this management style, management models are developed for children's playgrounds that are needed in open areas. Considering how important it is to play "games" for today's children, modeling should be established within certain standards.

Exercises performed with games provide opportunities for children to socialize by reacting to their peers while providing them with healthy development (Norton, et. al., 2004). Contrary to the widespread opinion of the society that playing games is a meaningless activity, a game that develops freely, spontaneously and by itself is very important in terms of contributing to the positive development of the cognitive, social and physical health of the child (Frost, 2010; Gray, 2011). Considering that mothers in the working class idealized house games in the middle of the 19th century (Stansell, 1982), the development and widespread use of children's playgrounds today is considered as a major reform movement. Gagen (2000), on the other hand, defines children's playground reformers as designers who teach children skills appropriate to their gender through activities and gain the habit of cleaning. Also, Ginsburg (2007) mentioned that the concept of "game" in the reports of American Pediatrics academics is necessary for the welfare of all children of the world. According to this report, it is recommended that children play for 90 minutes, provided they are outside. Although this situation is difficult for parents, educators and school counselors in terms of safety concerns, it has been observed that the participation of children in active play positively affects their primary health (Bjorkland \& Brown, 1998). Outdoor games and green space activities will also cause a decrease in 
The Effect of Environmental Factors on Children from The Viewpoint of Parents

stress levels. Researchers have suggested that the time spent in green spaces can make a difference even 5 minutes a day (Kuo \& Faber Tayler, 2004).

Playgrounds are designed for children to play and offer opportunities for both physical and social activities (Prellwitz \& Akar, 2007; Yllmaz and Bulut, 2007). In each of the playgrounds, children can both develop awareness of their environment and learn social names and values while playing (Stagnetti, 2004). While playing contributes to the psychological development and socialization of the child, it also positively affects their problem-solving skills and creativity and prepares them for life (Hamilton et al, 2001; White \& Stoecklin, 1998). While Gibson (1966) interpreted the environment and actions in children's playgrounds as primary perception objects, Heft (1988) emphasized the necessity of an ecological approach to children's behavior. Considering this situation, we should interpret games not as a cognitive state but as a form of behavior and action. Studies conducted in recent years have focused on the use of the environment as well as its accessibility. Usability is interpreted as the necessity for people to act on equal terms with others, to experience efficiency and to use the environment (Carlsson, 2004). The main thing is not what the child will do while playing, but how he/she will develop his/her intelligence. For this reason, the physical environments presented to the child are as important as the opportunities that develop their attitudes and addictions (Loebach, 2004). Children who cannot regularly interact with nature and grow away from natural environments are also at risk of being unable to develop environmental literacy skills (Bixler, et. al., 1994; Disigner \& Roth, 1992; Montessori, 1966). It is extremely important for children to interact with animals, plants and soil in terms of both getting to know the environment and gaining sensitivity to protect the environment. Environmental education practices made with games complete the education process by enabling children to interact with the environment regularly (Gülay, 2011). Any area that does not require a special design approach can be considered as a playground for children. For children, the garden of the house they live in, alleys and even empty plots are used as playgrounds where they can showcase their creativity. Val Plumwood, an environmental philosopher, (2002) interpreted this situation best as "He does not keep nature very separate from man, he thinks that man is a part of nature and he does not care about the use of nature for his own benefit".

When we look at public spaces, playgrounds are the places which families with small children prefer and where spend time most. These places, which are extremely important for families with children, are neglected due to the fact that the demands are not conveyed correctly and there are not enough green spaces in our cities. However, the quality and quantity of children's playgrounds is a criterion that determines the quality of life. Regular physical activities during childhood and adolescence also help the development of individuals' physiological and psychological health (Timmons, et. al., 2012). Despite increasing awareness of these benefits, there is a decrease in children's physical activity levels (Dollman, et. al., 2005). Many studies have indicated that preschool children are not active 
enough (Pate \& O'Neill, 2012). Considering that a school-age child needs at least 60 minutes or more of moderate-intensity activity every day, public health should be a priority to encourage regular physical activities (Broekhuizen, et.al., 2014). It has been proved by experts that a playground designed in integration with nature removes the psychological wear and tear of the child (Hamilton et al., 2001; Louv, 2012; Kytta, 2004), increases attention span by supporting attention tools (Wells \& Evans, 2003), gives a sense of calmness to children who are suffering from Attention Deficit Hyperactivity Disorder (ADHD) (Taylor et al., 2002) and increases social and physical skills (Barbour, 1999). While encouraging improvements are observed in peer engagement for children with Autism Spectrum Disorder (ASD) in play practices with peer participation in playgrounds (Kretzmann, et. al, 2015), it is also shown that the time they spend in playgrounds helps them socialize by healing their aggressive personality (Pepler, et. al., 1998).

Children born in a rapidly changing environment are more likely to face the negative effects of urban life. Early childhood education is an important factor in eliminating these negativities. The play movements that are made to have fun without thinking about the result provide opportunities for the child to learn the subjects that no one can teach with their own experiences (Gür, 2002). Playing games, which is the first step of education, also contributes positively to socialization and development. The most important criteria affecting the quality and quality of the design are the use of factors such as complex, connected, social, flexibility, challenging, improvable and security in children's playgrounds to be designed with the cooperation of designers and educators (Beckwith, 1985). In addition to this, it has been observed that with the right designs, children play longer in the field, exhibit calm behaviors share and increase their individual development (Koçyiğit et al., 2007). Therefore, movement is very important for a child's physical development. Today, adhering to the technological developments, adopting a sedentary lifestyle negatively affects the participation in physical activities and decreases the quality of life. The biggest age group affected by this lifestyle is children. Children's playgrounds that support the growth and development of children, provide active lifestyles, and prevent excessive weight gain by reducing the risk of diseases are seen as physical activity areas that are important for the physical development of children (Çelik, 2013).

The study is based on the fears that parents face while raising their children (kidnapping, harassment, self-harm, harming someone else, being excluded by their friends) and the main material of the study consists of the child and parents. In the study, children's playgrounds and users in the city of Rize were examined by associating children and games. The adequacy of children's playgrounds, which are offered as a temporary solution proposal in the city, and the concerns of parents when choosing these areas were also discussed. The study focused on the 
The Effect of Environmental Factors on Children from The Viewpoint of Parents

negativities faced by children who cannot play freely and by revealing their creativity under the pressure of their parents in children's playgrounds which positively affect the quality of urban spaces.

\section{RESEARCH METHOD}

\section{Sampled Areas}

Different professional disciplines, especially landscape architects, need to be sensitive to children's playground design, which support child development, which are sensitive to child health and psychology, and which include design approaches suitable for physical education. The inadequacy in the children's playgrounds also coincides with the lack of green space in the city. The quality of playgrounds as well as the playground planning per capita is very important in our cities which have limited space. Children's playgrounds have to be large enough to be used by different groups of ages, including different activities, with spatial and functional analyzes parallel to the city's green space system.

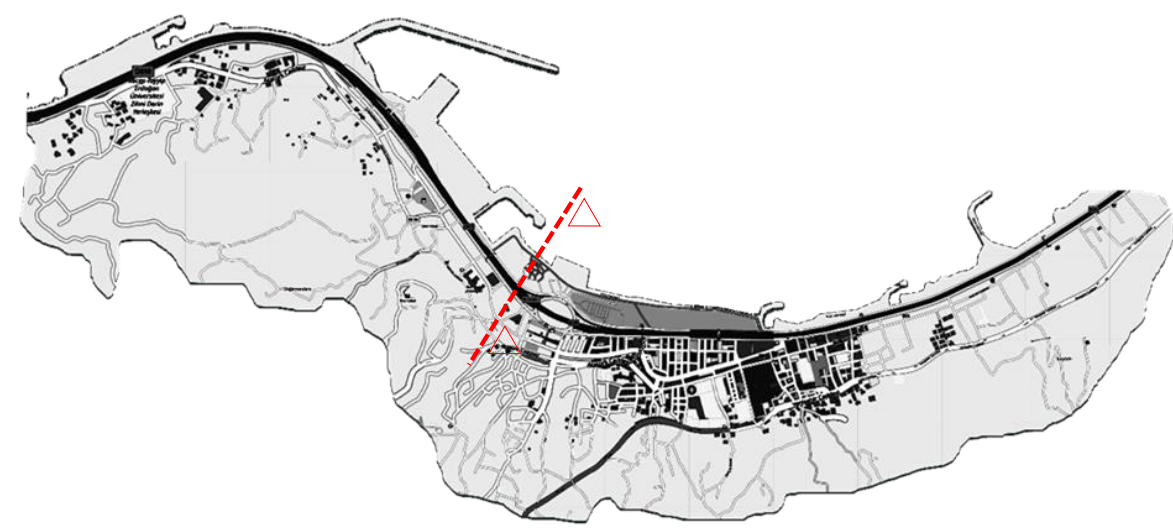

Figure 1. A selected sample of workspace in Turkey city (Example of Rize City).

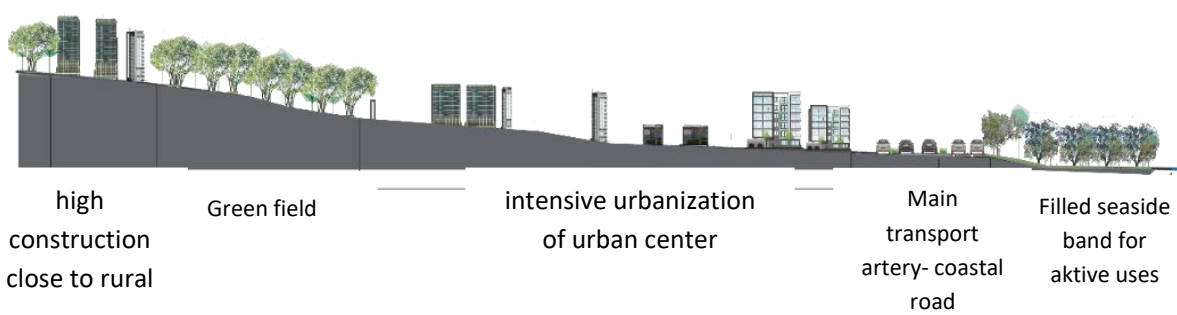

Although children's playground design approach criteria show variatior and cahnage over time, accessibility, security, diversity and charm, mixed use, correct material, socialization and user demand's criteria for landscape are still valid nowadays by what Friedberg (1982) has developed for children's playgrounds. When the criteria developed by Friedberg are evaluated at Rize urban scale (Figure 1), the importance given to the quality of life in the city of Rize is understood from the play areas per person. 


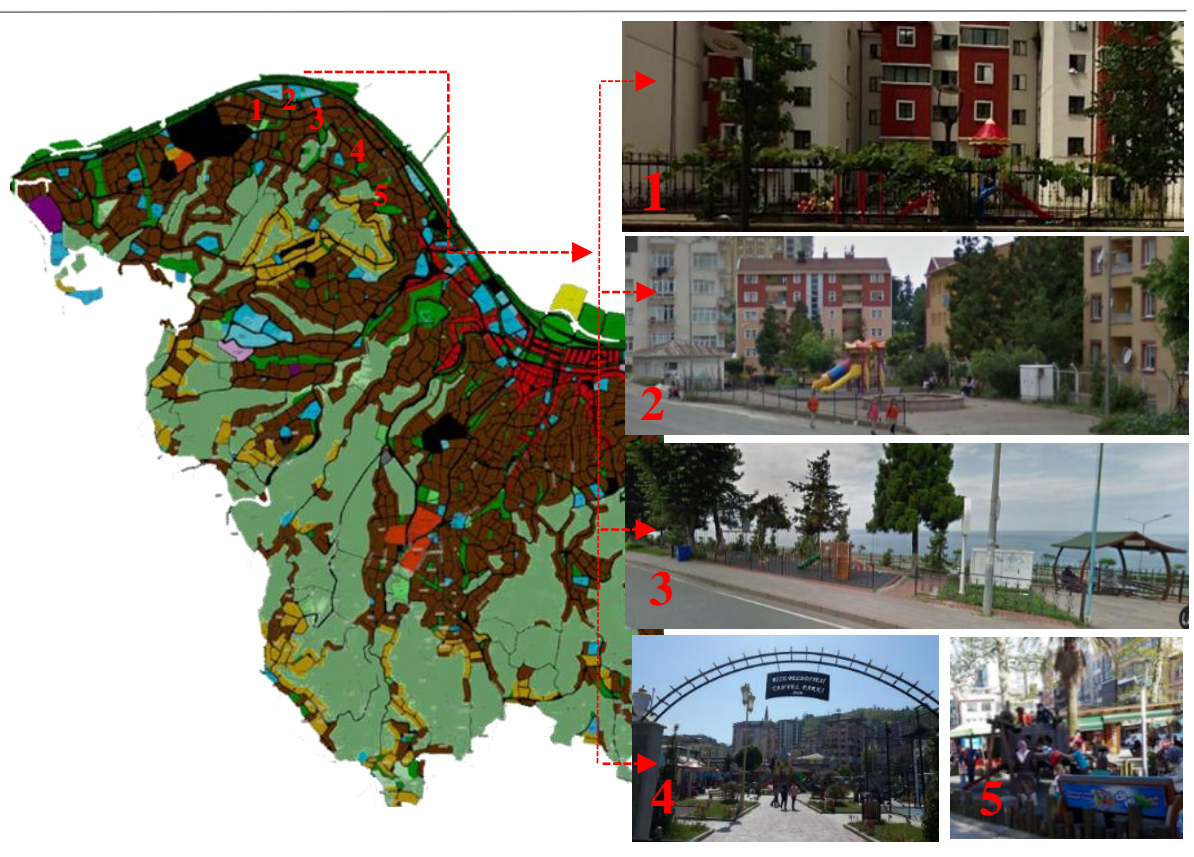

There are 5 children's playgrounds within the pedestrian and vehicle corridor extending from the Rize Fener District, which has developed as a new residential area, to the city center (Figure 2). The number of playgrounds on this route, which consists of approximately 10 neighborhoods, is very few. Spatial characteristics of the selected field to reveal the condition of the children's playground in Turkey show similarities with each other. These playgrounds were examined with Friedberg's evaluation criteria. It is found that these parks do not offer the diversity or even appeal to the users because of their proximity to the motorway. Also, they are preferred in a limited time period because they are located in unsafe, urban void areas. Besides, they have become neglected over time due to the choice of standard materials that comply with regional standards.

\section{Data Collection and Evaluation}

The study examined the concerns of parents on their children and the effect of environmental factors on children. In this study where environmental factors in children's play areas are questioned, (i) Examination of children's play areas by parents, (ii) Parents' sociodemographic characteristics and usage preferences for children's playgrounds and (iii) three different parameters are used to examine the parking criteria. In the first parameter, to be able to analyze the situation of parents in children's play areas. In Friedberg (1982), using the planning criteria developed for children's playgrounds (user demand criteria for accessibility, security, diversity and charm, mixed use, right materials, socialization and landscape) questions were prepared. The questionnaire questions are based on the environment where the child lives, the preferences and concerns of the parents, the desire of the child and the dependencies of the children. In the second parameter, the sociodemographic characteristics of the parents and their use preferences in
Figure 2. Children playgrounds selected from Rize city center (Rize city center- Fener District) 
The Effect of Environmental Factors on Children from The Viewpoint of Parents

children's play areas were examined and in the third parameter, the quality criteria (sociability, comfort and image, accessibility, usage and activities) that Altman and Zube (1989) developed were questioned on children's playgrounds. Two different forms were used in the evaluation of these three parameters: (1) questionnaire and (2) interviews.

Surveys conducted to reveal parents' concerns about children's playgrounds were conducted in the period between September and December 2018 and care was taken to ensure that the respondents were in the 0-14 age group. The closed-ended questions used in the questionnaires were administered to 150 parents, and children were not interviewed. Closed-ended questions were used in the questionnaires. In the statistical evaluation of the data, a correlation analysis was made between the socio-demographic status of the users and the concerns of the parents and Spearman coefficients ( $\mathrm{r}$ ) and their importance were determined. Statistical Package for Social Science (SPSS) 16.01 was used for statistical analysis. In addition, some data obtained from the surveys were evaluated by using \% analysis method. However, the children's playgrounds located between Rize city center and Fener district were examined by three different groups consisting of the lecturers of RTEU Faculty of Fine Arts, Design and Architecture, RTEU Administrative Staff, and RTEU Landscape Architecture Department Students using the quality criteria developed by Altman and Zube (1989). The opinions of 5 different people in each group were evaluated between 0-1 and the mean of each group was taken as a table.

\section{RESULTS}

Findings obtained in the study, which are in the context of ( $i$ ) Examination of children's play areas by parents, and (ii) the socio-demographic characteristics of parents and (iii) their use preferences for children's playgrounds, are included in the evaluation of park criteria.

\section{Evaluation of Children's Playgrounds by Parents}

While the children's playgrounds are evaluated according to the preferences of the parent users, the socio-demographic structures of the parents are examined and the significant relationships between gender, age, education, occupation, and income levels are given in Table 2. In the survey conducted within the scope of the study, significant relationships were found between $95 \%$ confidence level $(\mathrm{p}<0.05)$ and positive and negative questions. According to the correlation analysis results, the type of residence in which your child is living $\left(r=, 453^{* *}\right)$, how the child meets the playground needs $\left(r=, 218^{* *} ; r=, 380^{* *}\right)$ and how many hours a day he plays in the garden when the weather conditions are appropriate $\left(r=, 276^{* *} ; r=, 195^{*} ; r=, 181^{*}\right)$. In this context, it has been determined that these park areas, which are generally used as remote playgrounds, are usually four hours or more in children's playgrounds with no playgrounds in the garden (Table 1). 
Table 1. Examination of children's playgrounds by parents

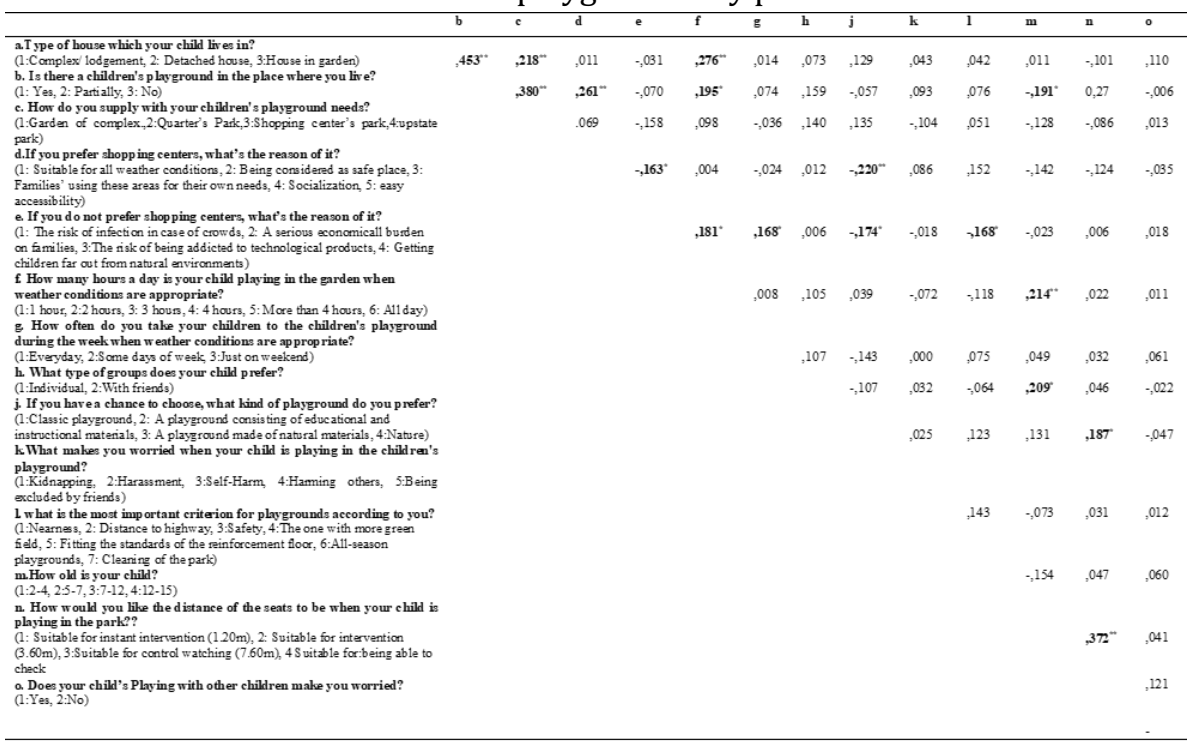

${ }^{* *}$ Correlation is significant at the 0.01 level (2-tailed); "Correlation is significant at the 0.05 level (2-tailed)

If the house does not have a children's playground, parents who have a small child (2-4 years old) ( $\left.r=-, 191^{*} ; r=, 214^{* *}\right)$ prefer the shopping centers that they think they are safe, suitable for all weather conditions $\left(r=, 261^{*}\right)$. In the case of crowded shopping mall where the risk of infection and financial reasons take place, they do not prefer $\left(r=-, 163^{*}\right)$. When the preference is offered, a natural playground consisting of natural materials is preferred $\left(r=-, 220^{*}\right)$. However, it is seen in (Table 1 ) that children who are older want to spend time with their friends in children's play areas $\left(r=, 209^{*}\right)$. Parents who prefer a classic playground wanted to be at a distance they could intervene to their children $\left(r=, 187^{*}\right)$ as the age of their children increased $\left(r=372^{* *}\right)$.

\section{The Relationships between Socio-Demographic Characteristics of Parents and Children's Playground Usage Preferences}

The questions directed to the users in the evaluations in Table 2 are discussed together with their socio-demographic structures. There was a positive correlation between gender and $\mathrm{g}, \mathrm{h}, \mathrm{k}, \mathrm{l}$, and $\mathrm{n}$ questions with $95 \%$ confidence level $(\mathrm{p}<0.05)$. Male parents only go to a children's playground where their children $\left(r=, 166^{*}\right)$ are taken care of $\left(r=, 247^{*}\right)$ at a children's playground $\left(r=, 176^{*}\right)$ they did not prefer the distance $(r$ $\left.=, 228^{* *}\right)$, but they were concerned by the exclusion and harm $\left(r=, 249^{* *}\right)$ of their children by their friends. It was also observed that the number of dwelling houses $\left(r=-, 221^{* *}\right)$ of the older parents $\left(r=, 191^{*}\right)$ whose children were older than others $\left(r=, 542^{* *}\right)$ decreased their control distances $\left(r=, 244^{* *}\right)$. There is a negative relationship between education level and housing type with 95\% confidence level $(\mathrm{p}<0.05)\left(r=-, 224^{* *}\right)$. It was found that children of parents who prefer to live on the site are small $\left(r=-, 245^{* *}\right)$ clean $\left(r=, 161^{*}\right)$ they preferred children's playgrounds $\left(r=-, 249^{* *}\right)$ more frequently and less-time use. Parents with good income 
The Effect of Environmental Factors on Children from The Viewpoint of Parents

status wanted that the shopping centers $\left(r=, 182^{*}\right)$ should be easily accessible $\left(r=, 210^{* *}\right)$, the use of educational and instructional materials $(r=-, 172 *$ ) should be included, and not to worry that their children can be harmed by others. Besides, housewives and unemployed parents prefer the classic children's playgrounds $\left(r=-, 195^{*}\right)$ because of being easily accessible $\left(r=, 163^{*}\right)$.

Table 2. Parents' socio-demographic characteristics and preferences of children's playgrounds

\begin{tabular}{|c|c|c|c|c|c|c|c|c|c|c|c|c|c|c|}
\hline & $a$ & b & c & d & e & $t$ & $g$ & h & $\mathrm{j}$ & $\mathrm{k}$ & 1 & m & n & $\circ$ \\
\hline $\begin{array}{l}\text { 1.Gender? } \\
\text { (1. Female, 2male) }\end{array}$ & -018 & -028 &,- 002 & $-0,049$ & -038 & - -029 & $.166^{\circ}$ & $247^{\prime \prime}$ & .068 & $249^{\prime \prime}$ & $.176^{\circ}$ & .152 & $.228^{\prime \prime}$ & $-0,15$ \\
\hline 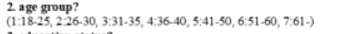 & .090 & $.221^{\prime \prime}$ & ,010 & .038 &, 008 & . 102 & $.191^{*}$ & , 143 & ,119 & ,095 & -052 & $.542^{\prime \prime}$ & $244^{\prime \prime}$ & .083 \\
\hline 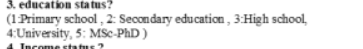 & $.224^{*}$ &,- 146 & -101 & ,043 & -0,037 & $-249^{\circ}$ & , 030 & -131 &, 076 & ,079 &, $160^{\circ}$ & $-245^{\prime \prime}$ & $-0,044$ & $-0,010$ \\
\hline 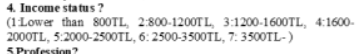 & $.224^{\prime \prime}$ & .060 & , $199^{\circ}$ & $210^{\prime \prime}$ & ,055 & -084 & 107 & ,003 & $172^{\circ}$ & $182^{*}$ & ,045 & ,005 & ,010 &, 004 \\
\hline 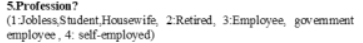 &, 030 & ,010 & ,005 &, $163^{*}$ & .044 & ,037 & , 136 & , 151 & $195^{\circ}$ & ,046 & , 025 & , 150 & .026 & $, 0,42$ \\
\hline
\end{tabular}

The percentage analysis method was applied with questions asked in the survey conducted to parents but other questions not questioned by the correlation analysis were analysed by percentage analysis method. According to this question, the answers to the question "if you prefer shopping mall, why do you prefer?" are as follows: $25,33 \%$ of the parents likes to use these areas to meet their own needs, $18,66 \%$ of them find those areas as safe, $14,66 \%$ find those places suitable for all kinds of weather conditions, 3,33\% for socialization, 3,33\% for easy access. Considering the reasons for not choosing shopping mall, $26 \%$ of parents think that those places keep children from the natural environment, $23,33 \%$ of them find them expensive, $15,33 \%$ of them because of the risk of infection in cases of crowded, $14 \%$ of them due to the fact that technological products are at risk of addiction. Parents' answers to the question "What are you worried about when your child is playing in the children's playground? "are 51,33\% abduction, $24,66 \%$ harassment, $13,33 \%$ self-harm, $10 \%$ others are harmed, and $0,66 \%$ exclusion by their friends. "What is the most important criterion for you in the game areas?" has the answers with $44 \%$ security, $20,66 \%$ closeness, $12 \%$ distance to vehicle road, $11,33 \%$ green area, $8 \%$ park clearance, $2 \%$ playgrounds that have been maintained in all seasons, $2 \%$ the ground in compliance with the standards. "Why would you like to be with your children?" has the answers as followings; $70 \%$ security, $10 \%$ ownership, 4,66\% spending time, 3,33\% control, and 1,3\% needs according to their importance.

\section{Parents' Park Criteria Preferences in Children's Playgrounds}

The characteristics of the children's playgrounds located between Rize city center and Fener district were evaluated according to the criteria developed by Altman and Zube (1989) (Socialiness, comfort and image, accessibility and usage, and activities). Selected areas was evaluated with a total of 3 points considering the current situation and the children's playgrounds they want to see entertainment, socialization, visibility, 
evening use, security, care, vegetable tissue, the attraction, proximity, ease of accessibility, availability of disability, permeability, recreational activities, and availability of food and beverage by RTEU, Faculty of Fine Arts, Design and Architecture, Landscape Architecture Sector, RTEU Administrative Staff and RTEU Landscape Architecture Department students (Table 3). The scoring was applied separately to faculty members in the department of Landscape Architecture, administrative staff at RTEU, and students in the department of Landscape Architecture at RTEU. In line with the children's playground design criteria, Altman and Zube's criterion was evaluated by each group as available (M) and desired (I) out of 3 points. The total (T) data in the evaluation were calculated by taking the arithmetic mean of the scoring.

Table 3. Relationships between parents' choices of park criteria's in children's playgrounds

\begin{tabular}{|c|c|c|c|c|c|c|}
\hline \multirow{2}{*}{ CRITERIA } & \multicolumn{2}{|l|}{$\mathbf{A}$} & \multicolumn{2}{|l|}{ B } & \multicolumn{2}{|l|}{$\mathbf{C}$} \\
\hline & M:0,6 & $\mathrm{I}: 2,8$ & $\mathrm{M}: 1,2$ & I:2,6 & M:0,8 & $\mathrm{I}: 2,8$ \\
\hline Sociability & \multicolumn{6}{|c|}{$\begin{array}{l}\text { Parents' sociality criteria, such as entertainment, socialization, visibility, } \\
\text { evening use, etc. social values in the direction of values. The emotions } \\
\text { gained by parents during quality times they spend with their children } \\
\text { and their interaction with other children in the place where their children } \\
\text { are located are very important in their personality development. The fact } \\
\text { that children's play areas are used in the night will increase the time } \\
\text { period that parents can spend with their children and will give positive } \\
\text { benefits to the development of the parent child relationship. The fact } \\
\text { that children's play areas are used at night will increase the time period } \\
\text { that parents can spend with their children and will give positive benefits } \\
\text { to the development of the parent child relationship. }\end{array}$} \\
\hline \multirow[b]{2}{*}{$\begin{array}{l}\text { Comfort and } \\
\text { Image }\end{array}$} & M:0,2 & I:3 & M:0,6 & $\mathrm{I}: 2,4$ & M:0,4 & I:2,8 \\
\hline & \multicolumn{6}{|c|}{$\begin{array}{l}\text { Safety is the most important element of comfort and image criteria, } \\
\text { which increases the preferability of playgrounds. Parents pay attention } \\
\text { to the fact that they prefer the places where they feel safe for their } \\
\text { children, and green texture. The feeling of responsibility towards the } \\
\text { environmental sensitivity that green tissue creates on children is } \\
\text { considered to be the most powerful achievement that parents can give } \\
\text { their children in the family environment. }\end{array}$} \\
\hline
\end{tabular}

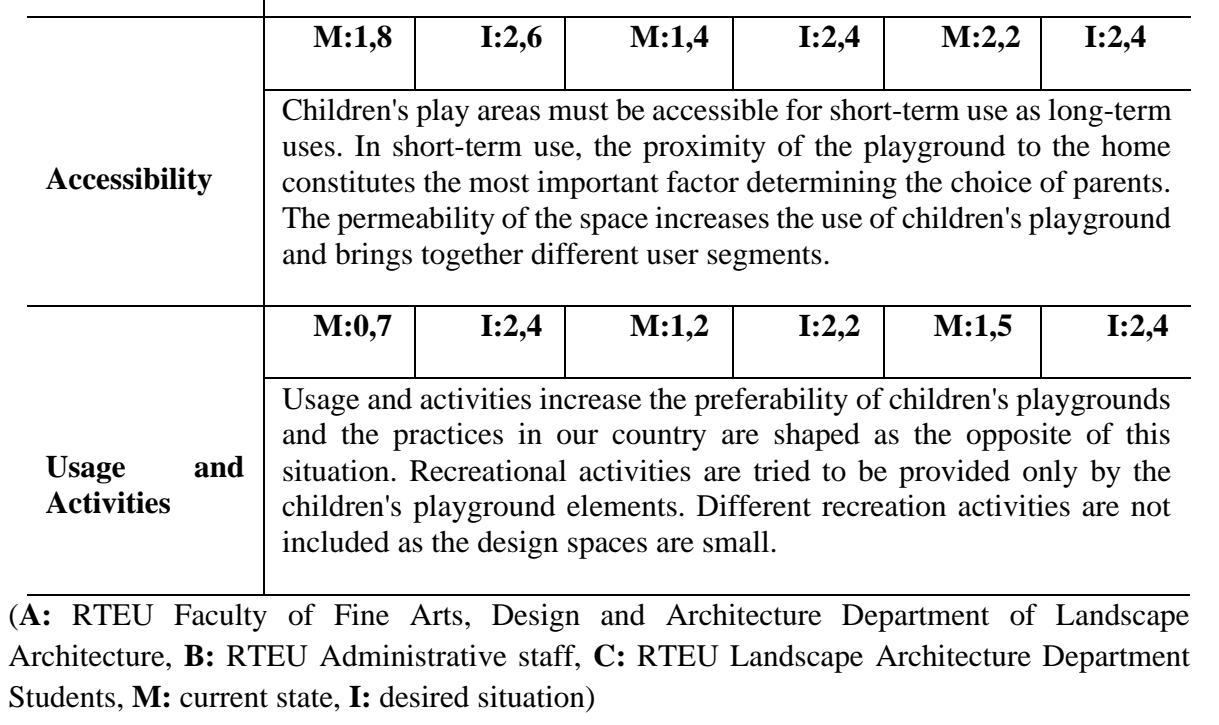


The Effect of Environmental Factors on Children from The Viewpoint of Parents

The current status of selected children's playgrounds can be reached by all parents (Total: 5,4), but they are found insufficient in terms of comfort and image criteria (T: 1,2). However, it is not sufficient in terms of usage and activities (T: 3,4) and it is preferred by users for socializing (T: 2,6). Expectations from children's play areas are listed as sociality (T: 8,2) and comfort and image (T: 8,2) criteria, mainly as accessibility (T: 7,4) and usage and activities (T: 7). Parents want the areas where they spend time to be safe, well-maintained, rich in plant tissue (green texture amount), use in the evening and visible places.

\section{DISCUSSION AND SUGGESTIONS}

The aim of the study is to understand the concerns of parents who allow their children to play in children's playgrounds in public spaces. The study showed that the parents face concerns about kidnapping, harassment and self-harm in addition to the physical injuries of their children. It has been observed that children need a natural environment in which they can demonstrate their abilities regardless of their experiences. In addition, it has been determined how important these natural environments are in the psychological and physical development of children. Socialization in public and private spaces to be created in cities is very important in childhood education (Filipovaa, et. al., 2016). These areas where children communicate with their environment are perceived as frightening or even dangerous (cemeteries, garbage dumps and cellars) when they are under the influence of irregular settlements (Georgieva, 2018). This perception is also addressed in the context of inequality. The inequality encountered in play groups used in children's playgrounds is also felt by children in different social status (Filipovaa, et. al., 2016). However, children know that playgrounds are designed for them. These areas are sometimes shaped by the perspective of the parents and sometimes the children. However, if the order demands of society norms and financial difficulties prevail in children's playgrounds, children's playground designs are affected. In this case, it reflects negatively on children's behavior. These playgrounds, which are seen as boring by children, cause disappointment in children and cause low usage (Jansson, 2008). Concerns about the design of the ideal playground differ between children and adults. While parents prioritize safety and hygiene, and politicians place emphasis on design and image, children place emphasis on pleasure and risk (Refshauge, et. al., 2012).

Today, children have to spend a lot of time in closed spaces (Karsten, 2005). This situation supports the parents' feelings of fear of strangers, gangs and traffic accidents (Clements, 2004). Parents accompanying young children in using the parking spaces cause children not to use the parking spaces freely (Veitch, et. al., 2006). Clements (2004) defined children's watching TV and playing computer games as the number one reason why they do not play outside. Louv (2008) stated that children are worried about this situation because of the little contact with nature and even the negative changes in their lifestyles. It is important to discuss and 
analyze general models in the development process in children's playgrounds. Ward's (1990) most striking comment is that every generation sacrifices street games for modern urbanization. During this period, street games have changed shape and survived to take advantage of environmental changes. However, it has been observed that today's children spend less time playing games in different areas than in the past (Wridt, 2004). This decline in time children spend in public playgrounds has created a spatial change in children. After this situation, activity places in children's playgrounds turned into indoor playgrounds such as paid game trade centers and took the form of playing games on personal computers, video games and internet environments (Wridt, 2004).

Difficulties faced by parents in supporting the social and physical development of children affect their children's active play needs and cause physical and mental disorders. The distances of the children's playgrounds used in the open green areas in our cities from the residential premises cause parents not to send their children to these points alone, therefore they cannot use the children's playgrounds together and for a long time. Although parents want to play their children in children's playgrounds designed with natural elements $\left(r=-, 163^{*}\right)$, the absence of such a children's playground in their environment requires their children to use fixed-equipped children's playgrounds. The activities to be carried out in small and crowded spaces with fixed equipment cannot contribute to the development of the child other than physically tiring them. The frequent use of the control mechanism by the parents in young children causes the parents to prefer indoor spaces (shopping malls) instead of outdoor use. Even if parents complain about the possibility of their children getting sick and putting an extra burden on their financial budget while using these places, they use these places quite often because they consider the safety of their children (the presence of a camera system). Parents who use children's playgrounds in urban open green spaces are most concerned about their children's kidnapping, harassment, and self-harm. The fact that these concerns are frequently felt today indicates that there is a security weakness in parents.

Public playgrounds constitute an important part of the play facilities for children. Therefore, the popularity of play equipment in children's playgrounds and their frequent use in games cause parents to worry (Norton, et. al., 2004). Children's safety is a top priority in school settings. Many accidents, especially in school playgrounds, range from minor abrasions to strikes; from fractures that require quick action to serious health problems (Taylor, 2020). It is observed that the games children play in the open air in schools are also threatening. The reasons can be put forward as follows: time can be better spent on academic pursuits, playground injuries encourage litigation, higher risk of contact with strangers threatens children, teachers and volunteers are less willing to supervise play activities. The value of play for the physical and mental development of children is unquestionable, but must be balanced by the 
The Effect of Environmental Factors on Children from The Viewpoint of Parents

minimum risk condition that prevents the child from being injured (Nixon, et. al., 1981). Head trauma or severe fractures with lifelong consequences should not be considered as part of growth (Norton, et. al., 2004). Lillıs and Jaffe (1997) stated that while child injuries are seen as an important source of illness and death in industrialized countries, many injuries also occur in children's playgrounds. The experiences and security levels of children while playing are the main points of children's playgrounds. Although these levels of control can be kept under control in schools, they cannot be controlled due to the combined use of different age groups in public children's playgrounds. Safety barriers used only in children's playgrounds cause parents to feel safe (Smith, 1998).

Should all risks in children's playgrounds be eliminated? The question is discussed by some experts. Grenn \& Hart (1998) stated that school-age children cannot find entertainment in a risk-free environment and these environments are boring for them. It has been emphasized that children's playgrounds and playground equipment to be designed considering these demands of children and parents' fears are necessary for children to explore, face difficulties, acquire new skills, even see and evaluate risks (Mitchell, et.al., 2004). Children's playground designs should include planning principles that provide opportunities for children's learning as they affect physical competence, play behaviors, and even peer relationships. In research in the field of developmental psychology, the importance of social and physical environmental conditions for children to develop a healthy development is constantly emphasized. But today, with the development of communication technology, electronic tools play a decisive role in the social environment of the child. From this perspective, the tools that shape the child's life, the world of meaning, consciousness, identity and play an active role in socialization appear as television and electronic games, not child game elements. Therefore, the current environment we live in prevents our communication with nature, dragging our children to a passive life (Çukur, 2011). This situation negatively affects the quality of the social and physical environmental conditions offered especially in the preschool period and the healthy development of the individual in terms of physical, spiritual, mental and social aspects. It should not be forgotten that childhood, which is the most important period for an individual to be a healthy adult, will contribute positively to his/her development when supported by social and physical activities.

\section{CONCLUSION}

In addition to the fears of children who play in children's playgrounds, their parents have been the subject of the study in their physical and mental development. This anxious perspective towards children's playgrounds has negatively affected the use of children's playgrounds and brought a critical perspective to the regulations. The awareness of parents about children's playgrounds and this increase in the level of anxiety has brought the necessity to take into account the weakness of 
security in the design of children's playgrounds. Some of the results have shown that the activities in the children's playgrounds do not fully support the socialization of children. The results show that most children need to take advantage of opportunities to play and interact with their peers. In addition to the safety needs of children, the safety concerns of their parents should also be taken into account in the new design approaches to be developed for children's playgrounds. The designed playgrounds should be designed not only as a place that allows physical play activities, but also as a meeting point where play and socialization interaction take place. For this reason, with the support of planners, designers and child psychologists, the playgrounds should be designed at social level as well as at individual level.

Although some of the results presented are the same as the information obtained in other studies, they differ in anxiety and concerns felt by the parents about the use of children's playgrounds. With globalization, the necessity for children to spend time at home in the pandemic period increases their individual use of technological devices and triggers the fear of "addiction" in parents. This situation shows us how important it is to spend time in nature. It has questioned the necessity of including children's playground designs that will improve children's health, encourage their creativity and sharpen their thinking skills in urban open green spaces. With the proposed design approaches, these areas will eliminate the concerns of parents as well as children and turn them into spaces that can be used safely over time. For future research, it has been concluded that studies should be carried out on nonusers of playgrounds, drawing attention to the fact that security needs are not met sufficiently in public playgrounds.

\section{CONFLICT OF INTEREST}

No conflict of interest was declared by the authors.

\section{FINANCIAL DISCLOSURE}

The authors declared that this study has received no financial support.

\section{ETHICS COMMITTEE APPROVAL}

Ethics committee approval was not required for this article.

\section{LEGAL PUBLIC/PRIVATE PERMISSIONS}

In this research, the necessary permissions were obtained from the relevant participants (individuals, institutions, and organizations) during the survey and in-depth interviews.

\section{REFERENCES}

Acar, H. (2016). Assessment of Children's Playgrounds in Terms of Design Approach, Physical Characteristics and User's Ideas, Environmental Sustainability and Landscape Management, Chapter 3, ISBN: 978-954-074140-6, ST. Kliment Ohridski University Press, Sofia, 35-57p. 
The Effect of Environmental Factors on Children from The Viewpoint of Parents

Acar, H. (2013). Landscape Design for Children and Their Environments In Urban Context. In: Özyavuz M. (Ed.) Advances In Landscape Architecture, Chapter 12, INTECH, Croatia, 291-324p.

Altman I., \& Zube E.H. (1989). Public places and spaces, Plenum Pub Corp.

Barbour, A. C. (1999). The impact of playground design on the play behaviors of children with differing levels of physical competence, Early Childhood Research Quartely, 14(1),75-98.

Beckwith J. (1985), When Children Play, Association for childhood Education International, US.

Belknap, E., \& Hazler, R. (2014). Empty Playgrounds and Anxious Children, Journal of Creativity in Mental Health, (12),210-231.

Bixler, R., Carlisle, D.L., Hammitt, W.E., \& Floyd, M.F. (1994). Observed Fears and Discomforts Among Urban Students on Field Trips to Wildland Areas, The Journal of Environmental Education, 26 (1),24-33.

Bjorkland, D., \& Brown, R. (1998). Physical play and cognitive development: Integrating activity, cognition, and education, Child Development, (69),604-606.

Blackford, H. (2004). Playground panopticism: ring-around-the-children, a pocketful of women, Childhood, 11(2),227-249.

Broekhuizen, K., Scholten, A. M., \& Vries, S. I. (2014). The value of (pre)school playgrounds for children's physical activity level: a systematic review, International Journal of Behavioral Nutrition and Physical Activity, 11(59),1-28.

Carlsson, G. (2004). Travelling by urban public transport: exploration of usability problems in a travel chain perspective, Scandinavian Journal of Occupational Therapy, (11),78-89.

Clements, R. (2004). An investigation of the status of outdoor play, Contemporary Issues in Early Childhood, (5), 68-80.

Çelik, A., \& Şahin, M. (2013). Sports and child development, Journal of Academic Social Science Studies, (6)1,467-478.

Çukur, D. (2011). Outdoor design that promotes healthy development in early childhood, SDU Faculty of Forestry Journal, (12), 70-76.

Disinger, J. F., \& Roth, C. E. (1992). Environmental Literacy (ERIC Digest EDO-SE-92-1), ERIC Clearinghouse for Science, Mathematics, and Environmental Education, [ED 351 201], Columbus, OH.

Dollman, J., Norton, K., \& Norton, L. (2005). Evidence for secular trends in children's physical activity behaviour, British Journal of Sports Medicine, 39(12), 892-897.

Farley, T. A., Meriwether, R. A., Baker, E. T., Rice., J. C., \& Webber, L. S. (2008). Where Do the Children Play? The Influence of Playground Equipment on Physical Activity of Children in Free Play, Human Kinetics Journals, 5(2),319-331.

Filipovaa, A. G., Syroeda, N. S., \& Goncharovaa, S. V. (2016). Children's Playgrounds and Everyday City Life of Childhood, International Journal of Environmental \& Science Education, 11(10),3406-341. 
Friedberg, M. P. (1982). Juvenile Play Areas, Chapter Seven in Handbook of speciality elements in architecture, Edited by A. Alpern, Mcgraw-Hill Book. Frost, J. (2010). A history of children's play and play environments: Toward a contemporary child-saving movement, ISBN-10:0415806208, New York, NY: Routledge. 268p.

Gagen, E.A. (2000). 'Playing the Part: Performing Gender in America's Playgrounds', in S. Holloway and G. Valentine (eds) Children's Geographies: Playing, Living, Learning, New York: Routledge, 213p.

Georgieva, M. (2018). “The children's subculture” problem in the area of pedagogical research, The Teacher of The Future, 23(1),161-165.

Gibson, J. J. (1966). The senses considered as perceptual systems, Huoghton Mifflin

Ginsburg, K. R. (2007). The importance of play in promoting healthy child development and maintaining strong parent-child bonds, Pediatrics, 119(1),182-191.

Gray, P. (2011). The decline of play and the rise of psychopathology in children and adolescents, American Journal of Play, (3),443-463.

Green, J., \& Hart, L. (1998). Children's views of accident risks and prevention: a qualitative study, Injury Prevention, (4),14-21.

Gülay, H. (2011). As the twig is bent, so grows the tree: The importance of environmental education in the first years of life, Tübav Bilim Dergisi, $4(3), 240-245$.

Gür, Ş. (2002). Children's Places, Yem Yayınevi, ISBN: 978599054, 304Pp.

Hamilton, I., Harrop, A., \& Street, C. (2001). The Value of Children's Play and Play Provision in England: A Literatura Review, New Policy Institute, United Kingdom

Heft, H. (1988). Affordances of children's environments: A functional approach to environmental description, Children's Environments Quarterly, 5(3),29-37.

Jansson, M. (2008). Children's Perspectives on Public Playgrounds in Two Swedish Communities, Children, Youth and Environment, 18(2), 88-109.

Karsten, L. (2005). It all used to be better? Different generations on continuity and change in urban children's daily use of space, Children's Geographies, (3),275-290.

Kretzmann, M., Shih, W., \& Kasari, C. (2015). Improving Peer Engagement of Children With Autism on the School Playground: A Randomized Controlled Trial, Behavior Therapy, 46(1),20-28.

Koçyiğit, S., Tuğluk, M.N., \& Kök, M. (2007). Game as an Educational Event in the Child's Development Process, 16p.

Kuo, F. E., \& Faber Taylor, A. (2004). A potential natural treatment for attention-deficit/hyperactivity disorder: Evidence from a national study, American Journal of Public Health, (94),1580-1586.

Kytta, M. (2004). The Extent of Children's Independent Mobility and the Number of Actualized Affordances as Criteria for Child-Friendly Environments, Journal of Environmental Psychology, (24),179-198. 
The Effect of Environmental Factors on Children from The Viewpoint of Parents

Lillıs, K., \& Jaffe, D. (1997). Playground injuries in children, Pediatric Emergency Care, 13(2),149-153.

Loebach, J. (2004). Designing Learning Environments For Children: An Affordance-Based Approach to Providing Developmentally Appropriate Settings. Master of Environmental Design Studies, Dalhousie University, Halifax, Nova Scotia.

Louv, R. (2012). The Last Child in Nature, TÜBITTAK Popüler Bilim Kitapları, ISBN: 978-975-403-512-4, Semih Ofset Matbaacılık, Ankara.

Mitchell, R., Cavanagh, M., \& Eager, D. (2006). Not all risk is bad, playgrounds as a learning environment for children, International Journal of Injury Control and Safety Promotion, 13(2),122-124.

Montessori, M. (1966). The Montessori Method. (Introduction by J.Mc. V. Hunt), seventh printing, New York.

Nixon, J., Pearn, J., \& Wilkey, I. (1981). Death during play: a study of playground and recreation deaths in children, National Library of Medicine, 283(6288), 410.

Norton, C., Nixon, J., \& Sibert, J. R. (2004). Playground injuries to children, Disease in Childhood, 89(2),103-108.

Pate, R. R., \& O'Neill, J. R. (2012). Physical activity guidelines for young children: an emerging consensus, Archives of Pediatrics and Adolescent Medicine, 166(12),1095-1096.

Pepler, D.J., Craig, W. M., \& Roberts, W. L. (1998). Observations of Aggressive and Nonaggressive Children on the School Playground, Merrill-Palmer Quarterly, 28(1),55-76.

Plumwood, V. (2002). Environmental culture: the ecological crisis of reason. London: Routledge.

Prellwitz, M., \& Skar, L. (2007). Usability of playgrounds for children with different abilities, Occupational Therapy International, 14(3),144-155.

Refshauge, A. D., Stigsdotter, U. K., \& Cosco, N. G. (2012). Adults' motivation for bringing their children to park playgrounds, Urban Forestry \& Urban Greening, 11(4),396-405.

Smoyer-Tomic, K. E., Hewko, J. N., \& Hodgson, M. J. (2004). Spatial accessibility and equity of playgrounds in Edmonton, Canada, The Canadian Geographer, 48(3),287-302.

Smith, S.J. (1998). Risk and Our Pedagogical Relation to Children: On the Playground and Beyond. Albany: State University of New York Press.

Stagnetti, K. (2004). Understanding play: the implications for play assessment, Australian Occu-pational Therapy Journal, (51), 3-12.

Stansell, C. (1982). 'Women, Children, and the Uses of the Streets: Class and Gender Conflicts in New York City, 1850-1860', Feminist Studies, 8(2), 309-35.

Taylor, E. (2020). Playgrounds, Injuries, and Data: Keeping Children Safe, NASN School Nurse, 35(5), 266-268.

Taylor, A. F., Kuo, F. E., \& Sullivan, W. C. (2002). View of Nature and Self Discipline: Evidence from Inner City Children, Journal of Environmental Psychology, (11)54-77. 
Timmons, B. W., Leblanc A. G., Carson, V., Connor Gorber, S., Dillman, C., Janssen, I., Kho, M. E., Spence, J.C., Stearns, J.A., \& Tremblay, M.S. (2012). Systematic review of physical activity and health in the early years (aged 0-4 years), Applied Physiology, Nutrition, and Metabolism, 37(4),773792.

Unicef Turkiye.

https://www.unicefturk.org/sayfa/turkiye

(25.04.2019):

Veitch, J., Bagley, S., Ball, K., \& Salmon, J. (2006). Where do children usually play? A qualitative study of parents' perceptions of influences on children's active free-play, Health \& Place, (12),383-393.

Ward, C. (1990). The Child in the City, ISBN:9780719912597, London: Bedford Square Press, 116p.

Wells, N. M., \& Evans, G. W. (2003). Nearby Nature A Buffer of Life Stress Among Rural Children, Environmental and Behavior, 35(3),311-330.

White, R., \& Stoecklin, V. L. (1998). Children's Outdoor Play \& Learning Environments: Returning to Nature. Early Childhood New, White Hutchinson Leisure \& Learning Group.

Wridt, P. J. (2004). An historical analysis of young people's use of public space, parks and playgrounds in New York City, Children, Youth and Environments, 14(1), 86-106.

Yllmaz, S., \& Bulut, Z. (2007). Analysis of user's characteristics of three different playgrounds in districts with different socio-economical conditions, Building and Environment, 42(10),3455-3460.

\section{Resume}

Banu Bekci received her master's and Phd. degrees from Black Sea Technical University in the major of Landscape architecture. She currently works at Recep Tayyip Erdogan University, Department of Landscape Architecture, as an associate Prof. 